\title{
Artelogie
}

Recherche sur les arts, le patrimoine et la littérature de l'Amérique latine

\section{Fotografia na América Latina Contemporânea}

\section{Charles Monteiro e Gonzalo Leiva Quijada}

\section{OpenEdition \\ Journals}

\section{Edição electrónica}

URL: https://journals.openedition.org/artelogie/1059

DOI: 10.4000/artelogie.1059

ISSN: 2115-6395

\section{Tradução(ões):}

Photographie contemporaine en Amérique latine - URL : https://journals.openedition.org/artelogie/ 1057 [fr]

Fotografía en América Latina Contemporánea - URL : https://journals.openedition.org/artelogie/1432 [es]

Editora

Association ESCAL

Refêrencia eletrónica

Charles Monteiro e Gonzalo Leiva Quijada, «Fotografia na América Latina Contemporânea», Artelogie [Online], 7 | 2015, posto online no dia 06 julho 2017, consultado o 11 abril 2022. URL: http:// journals.openedition.org/artelogie/1059; DOI: https://doi.org/10.4000/artelogie.1059

Este documento foi criado de forma automática no dia 11 abril 2022.

Association ESCAL 


\title{
Fotografia na América Latina Contemporânea
}

\author{
Charles Monteiro e Gonzalo Leiva Quijada
}

1 O dossiê sobre fotografia na América Latina Contemporânea se organiza a partir de três eixos estratégicos para refletir sobre a fotografia no âmbito nesse regional, como um território tanto de assimilação quanto de originalidade criativa. A reflexão transdisciplinar é uma perspectiva epistemológica para interpretar práticas e discursos que emergem de um território geográfico e mental, bem como de sistemas de representação mestiços que a fotografia da e na América Latina constroem e projetam com grande vitalidade e heterogeneidade.

2 O dossiê reúne um conjunto de 14 artigos que apontam para a riqueza e multiplicidade do campo atual de investigações sobre a fotografia em termos de temáticas, de abordagens, de perspectivas teóricas, bem como em termos geográficos (Argentina, Brasil, Chile, Colômbia, México, Uruguai, Venezuela) e de um arco de tempo que percorre desde a segunda metade do século XIX até o início do século XXI. Os artigos propõem reflexões teóricas e metodológicas interdisciplinares sobre a fotografia em diálogo com os campos dos Estudos Visuais, da História da Arte, Da Estética, da História e da Antropologia. O corpo, a paisagem, as identidades, os distintos olhares sobre as populações autóctones, as disputas políticas na elaboração de imaginários nacionais e a construção de uma imagem do poder são temas recorrentes nessa edição. Os autores responderam plenamente ao desafio lançado pelos organizadores para pensar o olhar e a visão como construtos artísticos, científicos, culturais, políticos e sociais no tempo. Também refletiram sobre os circuitos de produção, circulação e usos sociais das imagens fotográficas, com o objetivo de compreender a construção imaginária de representações e de significados sociais em disputa. O conjunto de artigos está organizado em três eixos principais: Imaginários e memórias, Estéticas e antropologias, Práticas e linguagens fotográficas.

3 No primeiro eixo, Imaginários e memórias, observa-se um conjunto de artigos que reflete sobre a construção de imaginários políticos e sociais através da fotografia. Magdalena Broquetas problematiza o novo imaginário nacional moderno em disputa através da 
revista ilustrada "Mundo Uruguayo" de ampla circulação em princípio do século XX. Carlos Alberto Sampaio Barbosa problematiza a relação fotografia e engajamento político que provoca "Frente a Frente" às revistas mexicanas entre propostas que unificam discursos sobre cultura proletária, realismo socialista e vanguarda. Alberto del Castillo Troncoso analisa a narrativa construída pela imprensa e os fotojornalistas sobre o massacre de a poblacção civil (estudantes) na Plaza de Las Tres Culturas de Tlatelolco, el 2 de octubre de 1968. Juanita Solano Roa discute como a fotografia ajudou a legitimar a perseguição e a eliminação de lideres que se opunham ao governo do Presidente Rafael Reyes na Colômbia, em decorrência do atentado de 10 de fevereiro de 1907. Gonzalo Leiva investgou a historia da fotográfica chilena a partir de dois eixos de representação historicistas que caracterizam linhas de produção recorrentes até os dias atuais : a paisagem e o corpo. Cora Gamarnik problematiza as fotografias veiculadas na imprensa, o uso da violência e as disputas políticas na sociedade Argentina pósditadura militar, no contexto do processo de abertura e em relação às tensões que antecedem as eleições de 1985.

No segundo eixo Estéticas y Antropologías, problematiza-se o conceito de fotografia e identidades latino-americanas, bem como os diferentes olhares sobre as elites, as populações nativas, os afro-brasileiros e o processo de modernização na América Latina. Mathieu Corp discute a categoria "Fotografia latinoamericana", cujo emprego seria tão problemática quanto o da categoria identidade latinoamericana, pois ambas encobririam sob o manto de uma pretensa homogeneidade um conjunto de práticas sociais muito diferentes e também projetos fotográficos singulares. Geraldine Guzman aborda a construção de uma visualidade para a nação através de um álbum de fotografias de Buenos Aires no contexto de grandes transformações sociais no país entre os anos 1880 e 1900. Alejandra Reyero analisa a fotografia etnográfica produzida sobre povos indígenas do Gran Chaco argentino como espaços de dissenso em relação aos usos e sentidos tradicionais, rompendo com o exotismo e permitindo uma participação ativa dos representados na construção de sua imagem. Ana Butto, Dánae Fiore e María José Saletta abordam a produção de imagens sobre os toldos tehuelches na Patagônia, entre Argentina e Chile, do começo do século XIX até início do século XX, problematizando os distintos olhares, a permanência de certos objetos e as particularidades de cada forma de representação (desenho, litografia e fotografia).

No terceiro eixo, Práticas e linguagens fotográficas, os artigos abordam os usos e funções do retrato no século XIX, os distintos olhares entre a tradição e arte sobre afrobrasileiros, as relações entre fotojornalismo e fotodocumentarismo, o diálogo possível entre a fotografia etnográfica e artística. Ana Maria Mauad discute as possibilidades de se pensar sobre as elites e a construção de uma imagem da sociedade brasileira através de uma coleção de retratos. Alice Heeren aborda o diálogo e o distanciamento da estética fotográfica de Mario Cravo Neto da tradição da fotografia etnográfica e documental brasileira. Charles Monteiro analisa as transformações do campo da fotografia e sua institucionalização nos anos 1970 e 80 através da passagem do engajamento político dos fotojornalistas a uma posição mais autoral e artística reivindicada pelos fotodocumentaristas. Fernanda Aguiar Carneiro Martins avalia o diálogo entre antropologia e arte presente no projeto fotográfico "Translitorânea" de Andrea Eichenberger, que retratou os habitantes das margens da rodovia federal BR 101 que se estende do Sul ao Norte do Brasil. Lisa Blackmore discute a multiplicação e os usos das imagens na internet na América Latina em estudo de um caso sobre o trabalho da artista venezuelana Érika Ordosgoitti, que através de fotografias do corpo em 
performances em espaços públicos. Suas fotografias difundidas pelo Facebook provocam novas perspectivas sobre o corpo questionando as formas hegemônicas de comunicação e de construção do olhar.

6 Através desse dossiê pretendemos provocar o debate reflexivo sobre os diferentes usos sociais, identidades, poderes e modos de ver as sociedades latino-americanas através da fotografia. Esperamos alimentar um debate sobre o médium fotográfico e seus desdobramentos, iniciado nos anos 1970. Buscamos problematizar os estereótipos e os preconceitos construídos pela/ sobre a fotografia na America Latina contemporânea através de uma revisão crítica e uma nova visada, buscando propor novas pautas de discussão e também a formação de novas redes de investigação sobre o tema. Charles Monteiro (PUC-RS/Brasil) Gonzalo Leiva (PUC-Chile) Abril de 2015.

\section{RESUMOS}

O dossiê sobre fotografia na América Latina Contemporânea se organiza a partir de três eixos estratégicos para refletir sobre a fotografia no âmbito nesse regional, como um território tanto de assimilação quanto de originalidade criativa. A reflexão transdisciplinar é uma perspectiva epistemológica para interpretar práticas e discursos que emergem de um território geográfico e mental, bem como de sistemas de representação mestiços que a fotografia da e na América Latina constroem e projetam com grande vitalidade e heterogeneidade.

\section{ÍNDICE}

Palavras-chave: fotografia, América Latina, imaginários, memórias, estéticas, antropologias, práticas, linguagens fotográficas

\section{AUTORES}

\section{CHARLES MONTEIRO}

(PUC-RSBrasil)

GONZALO LEIVA QUIJADA

(PUC-Chile) 